\title{
Theophylline is able to partially revert cachexia in tumour-bearing rats
}

\author{
Mireia Olivan ${ }^{1 *}$, Jochen Springer ${ }^{3}$, Sílvia Busquets ${ }^{1,2}$, Anika Tschirner $^{3}$, Maite Figueras ${ }^{1}$, Miriam Toledo ${ }^{1}$, \\ Cibely Fontes-Oliveira ${ }^{1}$, Maria Inés Genovese ${ }^{1}$, Paula Ventura da Silva ${ }^{1}$, Angelica Sette ${ }^{1}$, \\ Francisco J López-Soriano ${ }^{1,2}$, Stefan Anker $^{3}$ and Josep M Argilés ${ }^{1,2}$
}

\begin{abstract}
Background and aims: The aim of the present investigation was to examine the anti-wasting effects of theophylline (a methylxantine present in tea leaves) on a rat model of cancer cachexia.

Methods: The in vitro effects of the nutraceuticals on proteolysis were examined on muscle cell cultures submitted to hyperthermia. Individual muscle weights, muscle gene expression, body composition and cardiac function were measured in rats bearing the Yoshida AH-130 ascites hepatoma, following theophylline treatment.

Results: Theophylline treatment inhibited proteolysis in C2C12 cell line and resulted in an anti-proteolytic effect on muscle tissue (soleus and heart), which was associated with a decrease in circulating TNF-alpha levels and with a decreased proteolytic systems gene expression. Treatment with the nutraceutical also resulted in an improvement in body composition and cardiac function.
\end{abstract}

Conclusion: Theophylline - alone or in combination with drugs - may be a candidate molecule for the treatment of cancer cachexia.

Keywords: Cachexia, Nutraceuticals, Muscle wasting, Proteolytic system, Heart

\section{Background}

The development of cancer cachexia is the most common manifestation of advanced malignant disease. Indeed, cachexia occurs in the majority of terminally ill cancer patients, and it is responsible for the death of $22 \%$ of cancer patients [1]. The abnormalities associated with cancer cachexia include anorexia, weight loss, muscle loss and atrophy, anaemia and alterations in carbohydrate, lipid and protein metabolism [2]. Some of these effects are associated also with anti-tumour treatment. The degree of cachexia is inversely correlated with the survival time of the patient and it always implies a poor prognosis [3]. Perhaps one of the most relevant characteristics of cachexia is that of asthenia, which reflects the important muscle wasting that takes place in the cachectic cancer patient [4]. Lean body mass depletion is one of the main

\footnotetext{
* Correspondence: mireiaolivan@gmail.com

'Cancer Research Group, Departament de Bioquímica i Biologia Molecular, Facultat de Biologia, Universitat de Barcelona, Diagonal 645, Barcelona 08028, Spain

Full list of author information is available at the end of the article
}

trends of cachexia and it involves not only skeletal muscle but it also affects cardiac proteins, resulting in important alterations in heart performance. In addition to the increased muscle protein degradation found during cancer growth, the presence of the tumour also induces an increased rate of DNA fragmentation in skeletal muscle in both rats and mice [5].

One of the factors contributing to wasting during cancer is muscle loss through the activation of proteolysis [6]. The precise mechanism by which intracellular proteins are degraded is not fully understood, although it is accepted that proteolysis may occur inside and outside the lysosomes. The ATP-ubiquitin-dependent proteolytic system has been shown to be involved in the alterations of protein metabolism related to several pathophysiological conditions such as cancer, chronic infection and chronic heart failure [7]. During these pathological conditions commented on, muscle wasting leads to cachexia, a syndrome characterized by weight loss and profound metabolic abnormalities. Unfortunately therapeutic approaches to stop muscle wasting have not been very

\section{Biomed Central}

(c) 2012 Olivan et al.; licensee BioMed Central Ltd. This is an Open Access article distributed under the terms of the Creative Commons Attribution License (http://creativecommons.org/licenses/by/2.0), which permits unrestricted use, distribution, and reproduction in any medium, provided the original work is properly cited. 
satisfactory, partly because of the toxicity of inhibitors of the ubiquitin-dependent proteolytic system.

Theophylline (1,3-dimethylxanthine) is an alkaloid that belongs to the same family as caffeine and theobromine [8]. It is present in tealeaves and chocolate and its main effects seem related with relaxation of bronchial muscles together with peripheral blood vessel dilatation [9]. It is for this reason that the alkaloid has been used in the treatment of asthma and patients with chronic obstructive pulmonary disease (COPD) [10,11]. In addition, theophylline decreases circulating TNF- $\alpha$ and increases plasma IL10, an anti-inflammatory cytokine [12]. Additionally, theophylline is able to increase both the expression and the amount of the gene PPAR- $\gamma$, therefore suggesting an additional anti-inflammatory potential [13].

Taking into consideration its anti-inflammatory properties, theophylline could be a good candidate for the treatment of muscle wasting. Bearing this in mind, we have investigated the effects of theophylline treatment both in vitro, in an hyperthermia model which we previously reported as a suitable model for studying the antiproteolytic potential of drugs used in the treatment of muscle wasting [14], and in vivo, in rats bearing the Yoshida AH-130 ascites hepatoma, a tumour which induces a high degree of muscle wasting associated with cachexia.

\section{Methods}

\section{Cell culture}

C2C12 mouse skeletal muscle cells were obtained from the American Type Culture Collection. Cells were passaged in high-glucose Dulbecco's modified Eagle's medium (DMEM) supplemented with 10\% fetal bovine serum (FBS), $100 \mathrm{U} / \mathrm{mL}$ penicillin, $100 \mu \mathrm{g} / \mathrm{mL}$ streptomycin, $25 \mathrm{ng} / \mathrm{ml}$ fungizone, $110 \mu \mathrm{g} / \mathrm{mL}$ sodium pyruvate, and $2 \mathrm{mM}$ L-glutamine, in a humidified atmosphere of $5 \% \mathrm{CO}_{2}$ and $95 \%$ air at $37^{\circ} \mathrm{C}$. For experimental analyses, cells were seeded at $3.7 \times 10^{4}$ cells $/ \mathrm{cm}^{2}$ in $10 \% \mathrm{FBS} /$ DMEM until they reached $90-100 \%$ confluence $24 \mathrm{~h}$ later. At this time, the medium was replaced by DMEM containing $10 \%$ horse serum (HS) for induction of differentiation for genetically modified cells. Abundant myotube formation, monitored microscopically, occurred after 4 days in $10 \%$ horse serum HS/DMEM. Such fused myotube cultures were utilized for experimental analysis 5 days after transferring the cells to $10 \%$ HS/DMEM.

\section{Hyperthermia model and measurement of protein degradation}

C2C12 myotubes were pre-labelled with $\mathrm{L}-\left[2,6-{ }^{3} \mathrm{H}\right]$ phenylalanine (Amersham, Bucks, UK) as described [15] for a $24 \mathrm{~h}$ period, after which they were washed extensively in PBS, and incubated in fresh DMEM for a $2 \mathrm{~h}$ period at $37^{\circ} \mathrm{C}$, until no more radioactivity appeared in the medium. Protein degradation was measured by the release of $\left[2,6-{ }^{3} \mathrm{H}\right]$ phenylalanine into the medium (DMEM-supplemented with $1 \%$ glutamine, $1 \%$ penicillinstreptomycin-fungizone and 10\%HS) after $6 \mathrm{~h}$ incubation at 37 or $41^{\circ} \mathrm{C}$ according to Gulve et al [16]. After the incubation, the cells were rinsed twice in PBS. Cultures were incubated with or without different concentrations of theophylline $(0.01$ and $0.1 \mathrm{mM})[17,18]$. The hyperthermia method to induce protein degradation has been previously described by Smith et al. [19].

\section{Animals}

Male Wistar rats (Harlan, Barcelona, Spain) of 5 weeks (initial body weight $=154 \mathrm{~g}$ ) of age were used in the different experiments. The animals were maintained at $22 \pm 2^{\circ} \mathrm{C}$ with a regular light-dark cycle (light on from 08:00 a.m. to 08:00 p.m.) and had free access to food and water. The food intake was measured daily. All animal manipulations were made in accordance with the European Community guidelines for the use of laboratory animals. Ethical approval was obtained from both the University of Barcelona and the Generalitat de Catalunya Ethics Comittees.

\section{Tumour inoculation and treatment}

Rats were divided into 2 groups namely control and tumour hosts. The tumour rats received an intraperitoneal inoculum of $10^{8} \mathrm{AH}-130$ Yoshida ascites hepatoma cells obtained from tumours that were in exponential phase of growth as previously described by our group $[6,20]$. The tumour group was divided into treated and untreated, the former being administered a daily intragastric (i.g.) dose of theophylline $(50 \mathrm{mg} / \mathrm{kg}$ body weight (bw), dissolved in corn oil) [9] and the latter a corresponding volume of solvent (corn oil). On day 7 after tumour transplantation, the animals, showing a high degree of cachexia accompanied by a marked weight loss [21], were weighed and anaesthetized with an i.p. injection of ketamine/xylazine mixture (3:1) (Imalgene ${ }^{\circledR}$ and Rompun ${ }^{\circledR}$ respectively). The tumour was harvested from the peritoneal cavity and its volume and number of cells evaluated. Tissues were rapidly excised, weighted, and frozen in liquid nitrogen.

\section{Body composition analysis}

A nuclear magnetic resonance spectroscopy device (EchoMRI-700 ${ }^{\mathrm{m}}$, Echo Medical Systems, Houston, TX) was used to assess body composition with a sensitivity of $2 \mathrm{~g}$. Fat, muscle, and tissue-free body fluids generate different signals in response to various radio frequency pulses at distinct static magnetic fields [22]. A series of radio pulses at $2 \mathrm{MHz}$ induce changes in magnetic polarization of hydrogen nuclei. These changes decay, or "relax", with different relaxation times in different substances (www.echomri.com). The analyser is sensitive to NMR relaxation times in a range containing those of fat, 
lean, and saline, and so it detects and differentiates their amounts. In this study, body composition was analysed one day before starting the treatment and one day before sacrifice (7 days), and the results are expressed as the difference between both measurements [23].

\section{Echocardiographic study}

Rats were anesthetized using 1.5\% isoflurane and laid in supine position on a platform with all legs taped to ECG electrodes for heart rate monitoring. Body temperature was monitored and maintained at $36-38^{\circ} \mathrm{C}$ using a heating pad. All hair was removed from the chest. A high resolution echocardiography system (Vevo 770; VisualSonics Inc, Toronto, Canada) was used. The following parameters were assessed using M-mode and: the thickness of intraventricular septum (IVS), Left ventricle diameter (LVD), posterior wall thickness (PWT). The LV end-diastolic volume (LV Vol dia) and end-systolic volume (LV Vol sys) were traced and calculated in B-mode to account for altered ventricular geometry [23]. In this study, echocardiography was performed one day before starting the treatment (results not shown) and one day before sacrifice (7 days).

\section{RNA isolation}

Total RNA from heart and soleus muscle was extracted by TriPureTM kit (Roche, Barcelona, Spain), a commercial modification of the acid guanidinium isothiocyanate/ phenol/ chloroform method [24].

\section{Real-time PCR (polymerase chain reaction)}

First-strand cDNA was synthesized from total RNA with oligo dT15 primers and random primers pdN6 by using a cDNA synthesis kit (Transcriptor Reverse Transcriptase, Roche, Barcelona, Spain). Analysis of mRNA levels for the genes from the different proteolytic systems was performed with primers designed to detect the following gene products: ubiquitin (Forward $5^{\prime}$ GATCCAGGA CAAGGAGGGC 3 ', Reverse $5^{\prime}$ CATCTTCCAGCTGCT TGCCT3/); E2 (Forward 5' AGGCGAAGATGGCGGT 3'; Reverse $5^{\prime}$ TCATGCCTGTCCACCTTGTA $3^{\prime}$ ); C2 (Forward 5' GTTTCCATTGGGATTGTTGG 3'; Reverse $5^{\prime}$ TGTTCCATTGGTTCATCAGC 3'); C8 proteasome subunit (Forward 5' CAACCATGACAACCTTCGTG 3'; Reverse $5^{\prime}$ GCCTCAAGC CTTCTCTT TG 3'); MuRF-1 (Forward $5^{\prime}$ ATCACTCAGGAGCAGGAGGA 3'; Reverse $5^{\prime}$ CTT GGCACTCAAGAGGAAGG $3^{\prime}$ ); Atrogin-1 (Forward 5' GTTTCCATTGGGATTGTTGG 3'; Reverse $5^{\prime}$ TGTTCCATTGGTTCATCAGC $3^{\prime}$ ); m-calpain (Forward $5^{\prime}$ TTGAGCTGCAGACCATC $3^{\prime}$; Reverse $5^{\prime}$ GCAGC TTGAAACCTGCTTCT $3^{\prime}$ ) and cathepsin B (Forward 5' CTGCTGAGGACCTGCTTAC 3'; Reverse $5^{\prime}$ CACAGGGAGGG ATGGTGTA $3^{\prime}$ ); $18 \mathrm{~S}$ (Forward $5^{\prime}$ CGCAGAATTCCCACTCCCGACCC $3^{\prime}$; Reverse $5^{\prime} \mathrm{C}$
CCAAGCTCCAACTA CGAG C 3'). To avoid the detection of possible contamination by genomic DNA, primers were designed in different exons. The real-time PCR was performed using a commercial kit (LightCycler TM FastStart DNA MasterPLUS SYBR Green I, Roche, Barcelona, Spain). The relative amount of all mRNA was calculated using comparative CT method. $18 \mathrm{~S}$ mRNA was used as the invariant control for all studies.

\section{Statistical analysis}

Statistical analysis of the data was performed by means of one-way and two-way analysis of variance (ANOVA) (post-test Duncan).

\section{Results and discussion}

In order to test the proteolytic modulatory capacity of theophylline (a nutraceutical present in tea), we chose the model of hyperthermia [19]. Indeed, $\mathrm{C} 2 \mathrm{C} 12$ cells exposed to $41^{\circ} \mathrm{C}$ for 6 hours demonstrated a significant increase in proteolytic rate, and theophylline was able to significantly reduce the proteolysis during hyperthermia (0.01 mM 9\% and $0.1 \mathrm{mM} \mathrm{10 \% )} \mathrm{(Figure} \mathrm{1).}$

Bearing in mind the results obtained in vitro, the next aim of the present investigation was to see if this alkaloid was also able to influence muscle proteolysis in vivo. We investigated the effects of theophylline treatment in rats bearing the Yoshida AH-130 ascites hepatoma. We have previously shown that the cachectic syndrome is invariably associated with weight loss with skeletal muscle waste in different experimental cancer models $[20,25]$ also observed in the present study (Figures 2 and $3)$. Theophylline treatment did not influence food intake in the tumour bearing animals, neither did it influence tumour growth (Figure 2). These results are in contrast

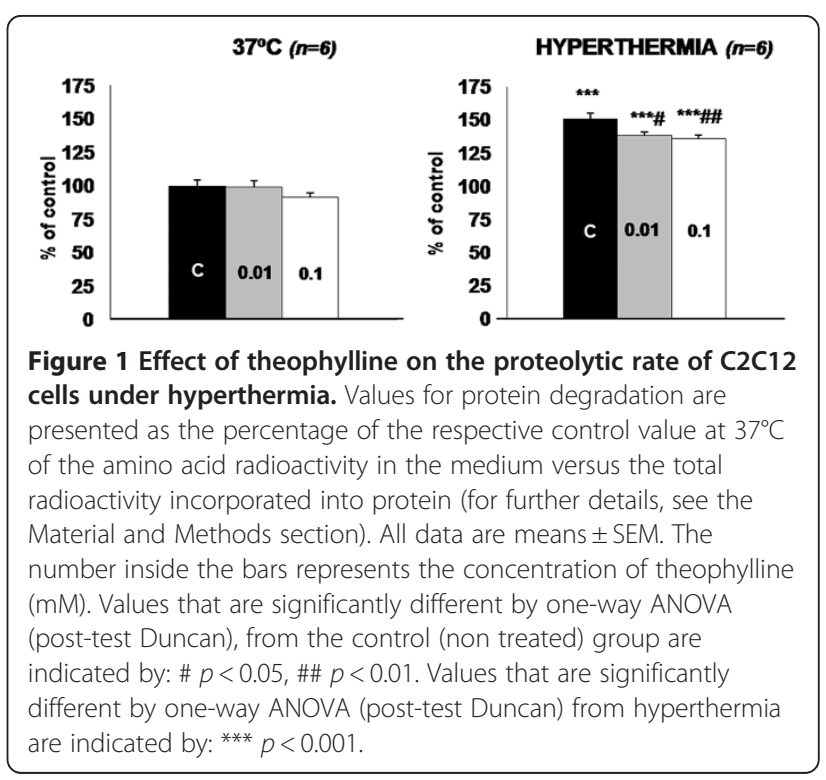




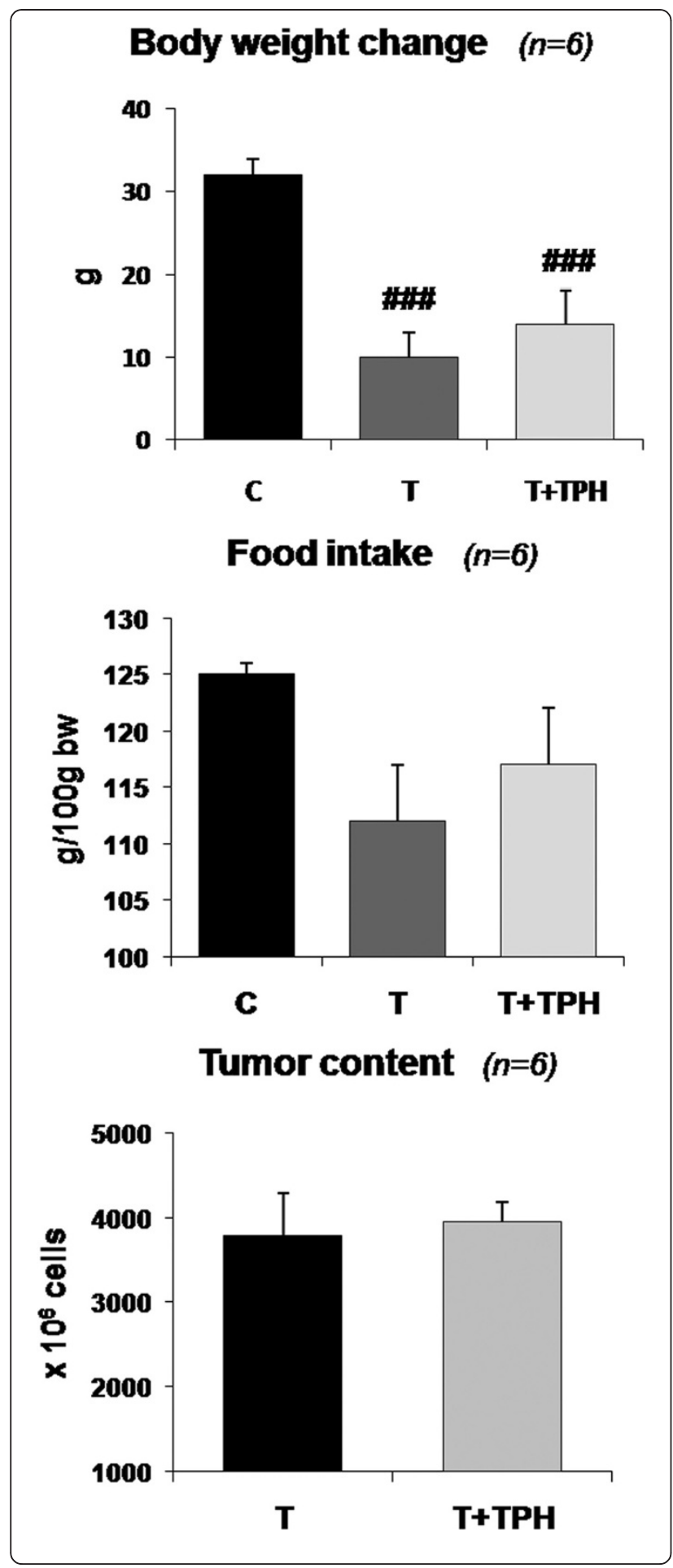

Figure 2 Effect of theophylline $(50 \mathrm{mg} / \mathrm{kg} \mathrm{bw}$ ) on body weight change, food intake and tumour content in rats bearing the Yoshida AH-130 ascites hepatoma. Results are mean \pm SEM. Body weight change is expressed as the difference between final body weight and initial body weight (IBW). Food intake is expressed in $\mathrm{g} / 100 \mathrm{~g}$ IBW and refers to the food ingested during the period of the experiment prior to sacrifice, which took place 7 days after tumour inoculation. Tumour cell content is expressed in millions of cells. $C=$ non-tumour-bearing rats, $\mathrm{T}=$ tumour-bearing rats, $\mathrm{T}+\mathrm{TPH}=$ tumour-bearing rats treated with theophylline. Values that are significantly different by two-way analysis of variance (ANOVA) are indicated by: \#\#\# $p<0.001$ (tumour effect).

with previous studies demonstrating that theophylline induces apoptosis and growth inhibition in tumour cells in vitro [26]; also, in vivo treatment with theophylline of mice implanted with melanoma cells results in a marked decrease in hepatic and pulmonary metastases [27].

From the results depicted in Figure 2 it can be seen that, in spite of the fact that theophylline treatment resulted in a tendency for higher body weight, the difference did not reach statistical significance. However, the treatment with this alkaloid resulted in a significant increase in the weight of soleus (10\%) and cardiac muscles (11.5\%), both of them with red and aerobic fibres (Figure 3). Conversely, no effects of treatment were observed with other muscles (non significant differences: gastrocnemius $\mathrm{T}=572 \pm 13$ (5) vs $\mathrm{T}+\mathrm{TPH}=580 \pm 12$ (6); EDL $\mathrm{T}=44 \pm 1$ (5) vs $\mathrm{T}+\mathrm{TPH}=43.7 \pm 1 \quad$ (6); tibialis $\mathrm{T}=184 \pm 6$ (5) vs $\mathrm{T}+\mathrm{TPH}=185 \pm 6$ (6)). These results are in agreement with the body composition of the animals. Indeed, as shown in Table 1, a significant decrease of fat and lean mass was observed due to the tumour growth. The treatment with theophylline resulted in a tendency for higher lean body mass, although the difference did not reach statistical significance. Interestingly, however, the animals treated with theophylline lost significantly less fat mass (Table 1 ). This observation is very

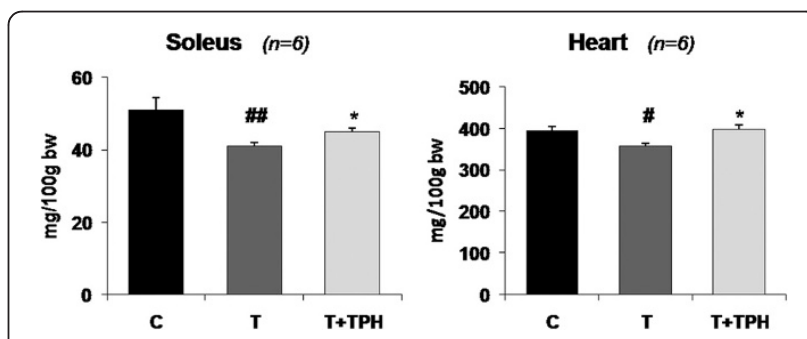

Figure 3 Effect of theophylline $(50 \mathrm{mg} / \mathrm{kg} \mathrm{bw})$ on soleus and heart weights in rats bearing the Yoshida $\mathrm{AH}-130$ ascites hepatoma. Results are mean \pm SEM. Muscles weights are expressed as mg/100 g of initial body weight (IBW). C = non-tumour-bearing rats, $\mathrm{T}=$ tumour-bearing rats, $\mathrm{T}+\mathrm{TPH}=$ tumour-bearing rats treated with theophylline. Values that are significantly different by two-way analysis of variance (ANOVA) are indicated by: \# $p<0.05$, \#\# $p<0.01$ (tumour effect); * $p<0.05$ (treatment effect). 
Table 1 Effects of theophylline ( $50 \mathrm{mg} / \mathrm{kg} \mathrm{bw}$ ) on body composition in rats bearing the Yoshida AH-130 ascites hepatoma

\begin{tabular}{|c|c|c|c|c|c|}
\hline & \multicolumn{3}{|c|}{ Experimental group } & \multirow{2}{*}{\multicolumn{2}{|c|}{ ANOVA }} \\
\hline & \multirow{2}{*}{$\underset{(n=6)}{C}$} & \multirow{2}{*}{$\begin{array}{c}\mathrm{T} \\
(n=10)\end{array}$} & \multirow{2}{*}{$\begin{array}{c}\text { T+ TPH } \\
(n=7)\end{array}$} & & \\
\hline & & & & $A$ & B \\
\hline Fat mass (g) & $3.2 \pm 1.1$ & $-4.3 \pm 0.5$ & $-2.3 \pm 0.7$ & 0,000 & 0,045 \\
\hline Lean body mass (g) & $23.5 \pm 1.5$ & $1.7 \pm 1.7$ & $7 \pm 3$ & 0,000 & ns \\
\hline Fluids (g) & $0.03 \pm 0.2$ & $-0.7 \pm 0.2$ & $0.04 \pm 0.3$ & 0,034 & 0,025 \\
\hline
\end{tabular}

surprising since theophylline has been demonstrated to be a lipolytic agent both in experimental animals [28] and humans [29], its mechanism of action being based on the inhibition of cAMP phosphodiesterase (PDE) [30]. These data suggest that an abnormal regulation of adipose tissue metabolism associated with tumour burden exists. The inhibition of PDE could be the mechanism underlying the effects of theophylline on muscle tissue, in this case on an aerobic muscle, this idea has been already suggested by others while studying muscle protein catabolism in septic rats [31].

Muscle catabolism associated with cancer is influenced by an activation of the ubiquitin-dependent proteolytic system [6]. Bearing this in mind, we decided to investigate the effects of theophylline on the gene expression of the different proteolytic systems. The results, presented in Table 2, show an increased expression of some genes involved in the ATP-ubiquitin-dependent proteolytic pathway in heart (ubiquitin, C2, C8, E2, MuRF-1 and Atrogin-1) and soleus muscle (ubiquitin, E2, Atrogin-1 and MuRF-1) of tumor-bearing animals in relation with the corresponding control animals. Tumourbearing theophylline-treated animals showed a decrease in the expression of ubiquitin (42\%) and MuRF-1 (53\%), an ubiquitin-dependent ligase that is muscle-specific, in soleus muscle. Theophylline caused a significant decrease in ubiquitin (41\%), proteasome subunits C2 (37\%), C8 (38\%) and E2 (49\%) in heart. A tendency to reduce MuRF-1 mRNA content was also observed with theophylline treatment, although the differences did not reach statistical significance.

Concerning other proteolytic systems, tumor burden also resulted in an increase in the expression of the calcium-dependent system $m$ - calpain and in the lysosomal cathepsin B in heart (Table 2). This proteolytic mechanism has also been shown to play a role in cancer cachexia [32]. Theophylline, in the heart, caused a significant decrease in m-calpain (45\%) mRNA, a component the calcium-dependent proteolytic system.

As previously stated, theophylline is able to have antiinflammatory effects [13]. Therefore, we examined the effects of the alkaloid on plasma cytokine levels. The results, depicted in Figure 4, show that the treatment significantly decreases TNF- $\alpha$, (significantly increased due to the presence of the tumour when compared with

Table 2 Effects of theophylline (50 $\mathrm{mg} / \mathrm{kg} \mathrm{bw}$ ) on soleus muscle and heart mRNA content of the different proteolytic systems in rats bearing the Yoshida AH-130 ascites hepatoma

\begin{tabular}{|c|c|c|c|c|c|c|c|c|c|c|}
\hline \multirow{3}{*}{ Treatment } & \multicolumn{3}{|c|}{ SOLEUS } & & & \multicolumn{3}{|c|}{ HEART } & & \\
\hline & \multirow{2}{*}{$\underset{(n=5)}{C}$} & \multirow{2}{*}{$\begin{array}{c}\mathrm{T} \\
(n=5)\end{array}$} & \multirow{2}{*}{$\begin{array}{c}\mathrm{T}+\mathrm{TPH} \\
(n=6)\end{array}$} & \multicolumn{2}{|c|}{ ANOVA } & \multirow{2}{*}{$\begin{array}{c}C \\
(n=5)\end{array}$} & \multirow{2}{*}{$\begin{array}{c}\mathrm{T} \\
(n=5)\end{array}$} & \multirow{2}{*}{$\begin{array}{c}\mathrm{T}+\mathrm{TPH} \\
(n=6)\end{array}$} & \multicolumn{2}{|c|}{ ANOVA } \\
\hline & & & & A & B & & & & A & B \\
\hline \multicolumn{11}{|l|}{ PROTEOLYTIC SYSTEM } \\
\hline \multicolumn{11}{|l|}{ Ubiquitin-dependent } \\
\hline Ubiquitin & $100 \pm 6$ & $204 \pm 15$ & $118 \pm 18$ & 0,000 & 0,001 & $100 \pm 5$ & $302 \pm 51$ & $177 \pm 32$ & 0,001 & 0,019 \\
\hline $\begin{array}{l}\text { Proteasome subunit } \\
\text { C2 }\end{array}$ & $100 \pm 13$ & $168 \pm 10$ & $160 \pm 40$ & ns & ns & $100 \pm 3$ & $303 \pm 47$ & $191 \pm 23$ & 0,000 & 0,010 \\
\hline $\begin{array}{l}\text { Proteasome subunit } \\
\text { C8 }\end{array}$ & $100 \pm 5$ & $111 \pm 8$ & $97 \pm 25$ & ns & ns & $100 \pm 3$ & $262 \pm 26$ & $164 \pm 22$ & 0,000 & 0,005 \\
\hline E2 & $100 \pm 5$ & $527 \pm 129$ & $288 \pm 80$ & 0,004 & 0,063 & $100 \pm 5$ & $224 \pm 55$ & $114 \pm 19$ & 0,013 & 0,025 \\
\hline MuRF-1 & $100 \pm 3$ & $171 \pm 19$ & $80 \pm 26$ & 0,025 & 0,007 & $100 \pm 3$ & $309 \pm 92$ & $177 \pm 38$ & 0,015 & ns \\
\hline Atrogin-1 & $100 \pm 8$ & $392 \pm 22$ & $362 \pm 71$ & 0,002 & ns & $100 \pm 3$ & $161 \pm 21$ & $152 \pm 21$ & 0,039 & ns \\
\hline \multicolumn{11}{|l|}{ Calcium-dependent } \\
\hline m-calpain & $100 \pm 4$ & $117 \pm 23$ & $142 \pm 43$ & ns & ns & $100 \pm 4$ & $307 \pm 58$ & $170 \pm 18$ & 0,001 & 0,009 \\
\hline \multicolumn{11}{|l|}{ Lysosomal } \\
\hline Cathepsin-B & $100 \pm 4$ & $111 \pm 8$ & $151 \pm 34$ & ns & ns & $100 \pm 2$ & $194 \pm 40$ & $111 \pm 13$ & 0,010 & ns \\
\hline
\end{tabular}

For further details, see the Material and Methods section. The results are expressed as a percentage of controls $(\mathrm{T})$. All data are mean \pm SEM. $\mathrm{C}=$ non-tumourbearing rats, $T=$ tumour-bearing rats, $T+T P H=$ tumour-bearing rats treated with theophylline. Statistical significance of the results by two-way analysis of variance (ANOVA) are indicated by: $n s$ (non-significant differences), A (tumour effect), B (treatment effect). 


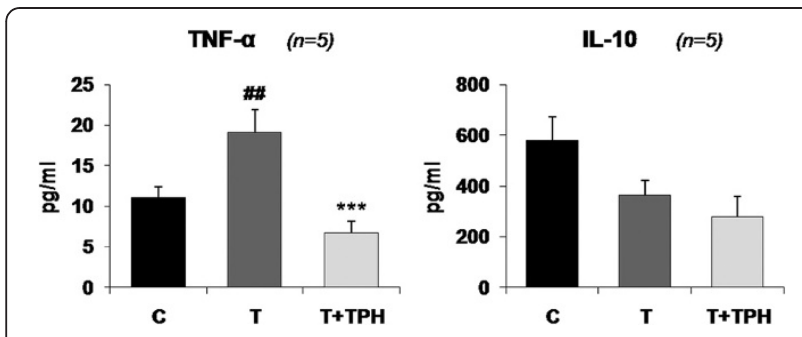

Figure 4 Effect of theophylline $(50 \mathrm{mg} / \mathrm{kg} \mathrm{bw})$ on circulating TNF- $\alpha$ and IL-10 concentrations in rats bearing the Yoshida AH-130 ascites hepatoma. Results are mean \pm SEM. The plasmatic concentrations of TNF- $a$ and IL-10 are expressed as pg/ml of plasma. $\mathrm{C}=$ non-tumour-bearing rats, $\mathrm{T}=$ tumour-bearing rats, $\mathrm{T}+\mathrm{TPH}=$ tumour-bearing rats treated with theophylline. Values that are significantly different by two-way analysis of variance (ANOVA) are indicated by: \#\# $p<0.01$ (tumour effect); ${ }^{* *} p<0.001$ (treatment effect).

control animals), while it had no effects on IL-10 (an anti-inflammatory cytokine). Since TNF- $\alpha$ has been shown to influence skeletal muscle proteolysis during cancer cachexia [33], one may speculate that the effects of theophylline on muscle weight and proteolysis could be accounted for the changes in this pro-cachectic cytokine [4].

Based on a clinical study with more than 4000 autopsy reports, Houten and Reilley [34] suggested that heart problems are responsible for at least $11 \%$ of cancer deaths. In fact, these data could be underestimated since a high percentage of deaths are actually attributed to infections, drug-induced toxicity and alterations in the osmotic balance, which are mainly due to heart problems. Therefore, more than $20 \%$ of the mortality is due to alterations in heart function. Indeed, McBride and collaborators [35] observed that more than $50 \%$ of multiple myeloma patients suffered cardiac failure during the neoplastic process. Data from our own laboratory also indicate that tumours implanted in experimental animals resulted in a decrease of the heart weight [20]. Drott and Lundholm [36] observed an increase in oxygen consumption associated with the heart in an experimental model of cancer. Important ultrastructural changes characterized by an increase in the ratio of myofibrilles/mitochondria and sarcomeric alterations in a similar way as observed during cardiac failure were also reported. Taking this into consideration, and also the observed effects of theophylline on cardiac mass, we decided to investigate heart parameters in the experimental rat model used in our study. The results presented in Table 3 show that implantation of the tumour resulted in a posterior wall thickness (PWT) size decrease. This was associated with a decreased left ventricle mass $(\mathrm{LV})$. Interestingly, treatment with theophylline increases these parameters, normalizing their values (Table 3).
Table 3 Effects of theophylline ( $50 \mathrm{mg} / \mathrm{kg} \mathrm{bw}$ ) on heart parameters in rats bearing the Yoshida AH-130 ascites hepatoma

\begin{tabular}{|c|c|c|c|c|c|}
\hline & \multicolumn{3}{|c|}{ Experimental group } & \multirow{2}{*}{\multicolumn{2}{|c|}{ ANOVA }} \\
\hline & \multirow{2}{*}{$\begin{array}{c}C \\
(n=5)\end{array}$} & \multirow{2}{*}{$\begin{array}{c}T \\
(n=8)\end{array}$} & \multirow{2}{*}{$\begin{array}{c}T+\text { TPH } \\
(n=9)\end{array}$} & & \\
\hline & & & & $\bar{A}$ & B \\
\hline $\begin{array}{l}\text { LV ejection } \\
\text { fraction (\%) }\end{array}$ & $77 \pm 2$ & $73 \pm 2$ & $72 \pm 3$ & ns & ns \\
\hline $\begin{array}{l}\text { Fractional } \\
\text { shortening } \\
\text { (\%) }\end{array}$ & $26 \pm 6$ & $23 \pm 1$ & $20 \pm 3$ & ns & ns \\
\hline LVD dia (mm) & $12 \pm 0.1$ & $2 \pm 0.3$ & $11 \pm 0.2$ & ns & ns \\
\hline LVD sys $(\mathrm{mm})$ & $9 \pm 0.7$ & $9 \pm 0.2$ & $10 \pm 0.4$ & ns & ns \\
\hline PWT dia (mm) & $2.6 \pm 0.1$ & $2.4 \pm 0.1$ & $3 \pm 0.1$ & ns & $\overline{0,012}$ \\
\hline PWT sys (mm) & $4 \pm 0.2$ & $3.2 \pm 0.2$ & $3.3 \pm 0.2$ & 0.05 & ns \\
\hline LV Vol dia $(\mu \mathrm{l})$ & $217 \pm 22$ & $220 \pm 14$ & $190 \pm 17$ & ns & ns \\
\hline LV Vol sys $(\mu \mathrm{l})$ & $50 \pm 8$ & $55 \pm 4$ & $48 \pm 7$ & ns & ns \\
\hline LVSV $(\mu \mathrm{l})$ & $167 \pm 15$ & $159 \pm 10$ & $139 \pm 14$ & ns & ns \\
\hline LVmass (mg) & $313 \pm 6$ & $274 \pm 10$ & $322 \pm 14$ & 0,032 & 0,005 \\
\hline
\end{tabular}

Echocardiographic data of non-tumour bearing rats $(C)$, tumour bearing rats $(T)$ and tumour bearing rats treated with theophylline $(T+T P H)$. Results are mean \pm SEM. LV ejection fraction: (LV vol dia-LV vol sys)/LV vol dia; fractional shortening: (LVD dia-LVD sys)/LVD sys; Left ventricle diameter in diastole: LVD dia; Left ventricle diameter in systole: LVD sys; posterior wall thickness in diastole: PWT dia; posterior wall thickness in systole: PWT sys; left ventricle volume in diastole: LV Vol dia; left ventricle volume in systole: LV Vol sys; left ventricle stroke volume: LVSV (LV Vol dia- LV Vol sys); left ventricle mass: LV mass (expressed as $\mathrm{mg} / 100 \mathrm{~g}$ of initial body weight). Statistical significance of the results by two-way analysis of variance (ANOVA); ns: non-significant differences. A (tumour effect); B (treatment effect).

\section{Conclusions}

From the results presented here, a potential role of theophylline in the treatment of the muscle wasting associated with cancer - particularly cardiac muscle - is postulated. Unfortunately, there is not a perfect therapeutic strategy for the treatment of muscle wasting associated with cancer. Although a plethora of treatments have been proposed, the use of a single drug does not seem to be an ideal approach [37]. It has become increasingly clear that a multifactorial approach is probably the most suitable treatment. Indeed, combinations of different nutraceuticals with high protein nutrition have been highly successful [38]. Theophylline could perhaps be used in combination with other nutraceuticals, nutrition or drugs in a new approach for the treatment of muscle wasting. Further work is therefore needed to evaluate the anti-wasting effects of theophylline in combination with other treatments.

\section{Competing interests}

All authors of this research have not conflict of interest related with employment, consultancies, stock ownership, honoraria, paid expert testimony, patent applications/ registrations, and grants or other funding.

\section{Authors' contributions}

Each author has participated sufficiently, intellectually or practically, in the work to take public responsibility for the content of the article, including the conception, design, and conduct of the experiment and for data 
interpretation (authorship). MO carried out the studies, sample analysis, and data analyses, performed the statistical analysis and helped to draft the manuscript. SB participated in the design and coordination of the study, carried out the studies, and helped to draft the manuscript. JS and MF participated in the design of the study and carried out the studies. AH, MT, CFO, MIG, PV and AS helped to carry out the studies. FJL-S, SA and JMA conceived the study, participated in the design, coordination of the study, drafted the manuscript and revised it critically. All authors have read and approved the final manuscript.

\section{Acknowledgements}

This work was supported by grant from the Ministerio de Ciencia y Tecnología (SAF-02284-2008)

\section{Author details}

${ }^{1}$ Cancer Research Group, Departament de Bioquímica i Biologia Molecular, Facultat de Biologia, Universitat de Barcelona, Diagonal 645, Barcelona 08028, Spain. ${ }^{2}$ Institut de Biomedicina de la Universitat de Barcelona, Barcelona, Spain. ${ }^{3}$ Division of Applied Cachexia Research, Department of Cardiology, Charité Medical School, Berlin, Germany.

Received: 3 November 2011 Accepted: 30 April 2012

Published: 21 August 2012

\section{References}

1. Warren S: The immediate causes of death in cancer. Am J Med Sci 1932, 184:610-615.

2. Argiles JM, Alvarez B, Lopez-Soriano FJ: The metabolic basis of cancer cachexia. Med Res Rev 1997, 17:477-498.

3. DeWys W: Management of cancer cachexia. Semin Oncol 1985, 12:452-460.

4. Argiles JM, Garcia-Martinez C, Llovera M, Lopez-Soriano FJ: The role of cytokines in muscle wasting: its relation with cancer cachexia. Med Res Rev 1992, 12:637-652.

5. van Royen M, Carbo N, Busquets S, Alvarez B, Quinn LS, Lopez-Soriano FJ, Argiles JM: DNA fragmentation occurs in skeletal muscle during tumor growth: A link with cancer cachexia? Biochem Biophys Res Commun 2000, 270:533-537.

6. Llovera M, Garcia-Martinez C, Agell N, Marzabal M, Lopez-Soriano FJ, Argiles $J M$ : Ubiquitin gene expression is increased in skeletal muscle of tumourbearing rats. FEBS Lett 1994, 338:311-318.

7. Argiles JM, Lopez-Soriano FJ: The ubiquitin-dependent proteolytic pathway in skeletal muscle: its role in pathological states. Trends Pharmacol Sci 1996, 17:223-226.

8. Friedman M: Overview of antibacterial, antitoxin, antiviral, and antifungal activities of tea flavonoids and teas. Mol Nutr Food Res 2007, 51:116-134.

9. Nyska A, Herbert RA, Chan PC, Haseman JK, Hailey JR: Theophyllineinduced mesenteric periarteritis in F344/N rats. Arch Toxicol 1998, 72:731-737.

10. Culpitt SV, de Matos C, Russell RE, Donnelly LE, Rogers DF, Barnes PJ: Effect of theophylline on induced sputum inflammatory indices and neutrophil chemotaxis in chronic obstructive pulmonary disease. Am J Respir Crit Care Med 2002, 165:1371-1376.

11. Zhou Y, Wang X, Zeng X, Qiu R, Xie J, Liu S, Zheng J, Zhong N, Ran P: Positive benefits of theophylline in a randomized, double-blind, parallelgroup, placebo-controlled study of low-dose, slow-release theophylline in the treatment of COPD for 1 year. Respirology 2006, 11:603-610.

12. Mascali JJ, Cvietusa P, Negri J, Borish L: Anti-inflammatory effects of theophylline: modulation of cytokine production. Ann Allergy Asthma Immunol 1996, 77:34-38.

13. Usami A, Ueki S, Ito W, Kobayashi Y, Chiba T, Mahemuti G, Oyamada H, Kamada Y, Fujita M, Kato H, Saito N, Kayaba H, Chihara J: Theophylline and dexamethasone induce peroxisome proliferator-activated receptorgamma expression in human eosinophils. Pharmacology 2006, 77:33-37.

14. Ametller E, Busquets S, Fuster G, Figueras MT, De Oliveira CC, Toledo M, Korzeniewska K, Argiles JM, Lopez-Soriano FJ: Effects of formoterol on protein metabolism in myotubes during hyperthermia. Muscle Nerve 2011, 43:268-273.

15. Alvarez B, Quinn LS, Busquets S, Lopez-Soriano FJ, Argiles JM: Direct effects of tumor necrosis factor alpha (TNF-alpha) on murine skeletal muscle cell lines. Bimodal effects on protein metabolism. Eur Cytokine Netw 2001, 12:399-410.

16. Gulve EA, Mabuchi K, Dice JF: Regulation of myosin and overall protein degradation in mouse C2 skeletal myotubes. J Cell Physiol 1991, 147:37-45.

17. Moonen HJ, Geraets L, Vaarhorst A, Bast A, Wouters EF, Hageman GJ: Theophylline prevents NAD + depletion via PARP-1 inhibition in human pulmonary epithelial cells. Biochem Biophys Res Commun 2005, 338:1805-1810.

18. Barnes PJ: Theophylline in chronic obstructive pulmonary disease: new horizons. Proc Am Thorac Soc 2005, 2:334-339. discussion 340-331.

19. Smith HJ, Khal J, Tisdale MJ: Downregulation of ubiquitin-dependent protein degradation in murine myotubes during hyperthermia by eicosapentaenoic acid. Biochem Biophys Res Commun 2005, 332:83-88.

20. Busquets S, Figueras MT, Fuster G, Almendro V, Moore-Carrasco R, Ametller E, Argiles JM, Lopez-Soriano FJ: Anticachectic effects of formoterol: a drug for potential treatment of muscle wasting. Cancer Res 2004, 64:6725-6731.

21. Tessitore L, Costelli P, Bonetti G, Baccino FM: Cancer cachexia, malnutrition, and tissue protein turnover in experimental animals. Arch Biochem Biophys 1993, 306:52-58

22. Tinsley FC, Taicher GZ, Heiman ML: Evaluation of a quantitative magnetic resonance method for mouse whole body composition analysis. Obes Res 2004, 12:150-160.

23. Akashi YJ, Palus S, Datta R, Halem H, Taylor JE, Thoene-Reineke C, Dong J, Thum T, Culler MD, Anker SD, Springer J: No effects of human ghrelin on cardiac function despite profound effects on body composition in a rat model of heart failure. Int J Cardiol 2009, 137:267-275.

24. Chomczynski P, Sacchi N: Single-step method of RNA isolation by acid guanidinium thiocyanate-phenol-chloroform extraction. Anal Biochem 1987, 162:156-159.

25. Busquets S, Fuster G, Ametller E, Olivan M, Figueras M, Costelli P, Carbo N, Argiles JM, Lopez-Soriano FJ: Resveratrol does not ameliorate muscle wasting in different types of cancer cachexia models. Clin Nutr 2007, 26:239-244.

26. Caraglia M, Marra M, Giuberti G, D'Alessandro AM, Beninati S, Lentini A, Pepe S, Boccellino M, Abbruzzese A: Theophylline-induced apoptosis is paralleled by protein kinase A-dependent tissue transglutaminase activation in cancer cells. J Biochem 2002, 132:45-52.

27. Lentini A, Vidal-Vanaclocha F, Facchiano F, Caraglia M, Abbruzzese A, Beninati S: Theophylline administration markedly reduces hepatic and pulmonary implantation of B16-F10 melanoma cells in mice. Melanoma Res 2000, 10:435-443.

28. Inoue H, Kobayashi-Hattori K, Horiuchi Y, Oishi Y, Arai S, Takita T: Regulation of the body fat percentage in developmental-stage rats by methylxanthine derivatives in a high-fat diet. Biosci Biotechnol Biochem 2006, 70:1134-1139.

29. Flechtner-Mors M, Jenkinson CP, Alt A, Biesalski HK, Adler G, Ditschuneit HH: Studies of phosphodiesterase effects on adipose tissue metabolism in obese subjects by the microdialysis technique. J Physiol Pharmacol 2005, 56:355-368.

30. Rabe KF, Magnussen H, Dent G: Theophylline and selective PDE inhibitors as bronchodilators and smooth muscle relaxants. Eur Respir J 1995, 8:637-642.

31. Lira EC, Graca FA, Goncalves DA, Zanon NM, Baviera AM, Strindberg L, Lonnroth P, Migliorini RH, Kettelhut IC, Navegantes LC: Cyclic adenosine monophosphate-phosphodiesterase inhibitors reduce skeletal muscle protein catabolism in septic rats. Shock 2007, 27:687-694.

32. Costelli P, Reffo P, Penna F, Autelli R, Bonelli G, Baccino FM: $\mathrm{Ca}(2+)$-dependent proteolysis in muscle wasting. Int J Biochem Cell Biol 2005, 37:2134-2146.

33. Lopez-Soriano J, Llovera M, Carbo N, Garcia-Martinez C, Lopez-Soriano FJ, Argiles JM: Lipid metabolism in tumour-bearing mice: studies with knockout mice for tumour necrosis factor receptor 1 protein. Mol Cell Endocrinol 1997, 132:93-99.

34. Houten L, Reilley AA: An investigation of the cause of death from cancer. J Surg Oncol 1980, 13:111-116.

35. McBride W, Jackman JD Jr, Grayburn PA: Prevalence and clinical characteristics of a high cardiac output state in patients with multiple myeloma. Am J Med 1990, 89:21-24.

36. Drott C, Lundholm K: Glucose uptake and amino acid metabolism in perfused hearts from tumor-bearing rats. J Surg Res 1990, 49:62-68. 
37. Argiles JM, Lopez-Soriano FJ, Busquets S: Novel approaches to the treatment of cachexia. Drug Discov Today 2008, 13:73-78.

38. van Norren K, Kegler D, Argiles JM, Luiking Y, Gorselink M, Laviano A, Arts K, Faber J, Jansen $H$, van der Beek EM, van Helvoort A: Dietary supplementation with a specific combination of high protein, leucine, and fish oil improves muscle function and daily activity in tumourbearing cachectic mice. Br J Cancer 2009, 100:713-722.

doi:10.1186/1743-7075-9-76

Cite this article as: Olivan et al.: Theophylline is able to partially revert cachexia in tumour-bearing rats. Nutrition \& Metabolism 2012 9:76.

\section{Submit your next manuscript to BioMed Central and take full advantage of:}

- Convenient online submission

- Thorough peer review

- No space constraints or color figure charges

- Immediate publication on acceptance

- Inclusion in PubMed, CAS, Scopus and Google Scholar

- Research which is freely available for redistribution 